\title{
ODBORNÉ POŽADAVKY NA ORGÁNY OBCÍ A ČLENY JEDNOTEK SBORŮ DOBROVOLNÝCH HASIČŮ OBCÍ V OBLASTI ŘEŠENÍ MIMOŘÁDNÝCH UDÁLOSTÍ A KRIZOVÝCH SITUACÍ
}

IX: 213-458, 2007

ISSN $1212-4117$

\author{
Aleš Kudlák, Jan Horák \\ Jihočeská univerzita vČeských Budějovicích, Zdravotně sociální fakulta, katedra radiologie \\ a toxikologie
}

\section{ÚVOD}

V dnešní době se stále více a více skloňuje spojení slov „rozmar počasí“, „globální oteplováni““, „změna klimatu“, „povodně“, ale také „technický rozvoj“, „aplikace nových technologii“", „kritická infrastruktura“ a v neposlední řadě „boj s terorismem“. Všechna vyjmenovaná sousloví nás zasahují, byt' i nevědomky, dnes a denně. Masmédia nám je přinášejí v podobě nejčerstvějších a zaručených zpráv. Na pracovištích o nich bud' hovoŕíme, anebo se dokonce s nimi setkáváme či s nimi pracujeme. Někteří z nás se $\mathrm{v}$ již zmiňovaných termínech podílejí na vědecké činnosti.

Všechny vyjmenované jevy či výdobytky dnešní společnosti kladou velkou zátěž, požadavky na odbornost a s tím spojenou odpovědnost na osoby, které mají zabezpečit a provádět ochranu života, zdraví, majetku a životního prostředí.

$\mathrm{V}$ našem příspěvku se zaměříme především na orgány obce všeobecně a na členy jednotek sborů dobrovolných hasičů, které obec ze zákona o požární ochraně zřizuje.

\section{ODBORNÉ POŽADAVKY NA ORGÁNY OBCE \\ Starosta}

Starosta obce musí při provádění záchranných a likvidačních prací zajistit varování osob nacházejících se na území obce před hrozícím nebezpečím, organizuje po dohodě s velitelem zásahu nebo se starostou obce s rozšířenou působností evakuaci osob z ohroženého území obce, organizuje činnost obce $\mathrm{v}$ podmínkách nouzového přežití obyvatel obce a je oprávněn vyzvat právnické a fyzické osoby k poskytnutí osobní nebo věcné pomoci. Tyto povinnosti řeší $\mathrm{v}$ př́padě, že se jedná o mimořádnou událost.

Nastane-li krizová situace spojená s vyhlášením krizového stavu, musí zabezpečit varování osob nacházejících se na území obce před hrozícím nebezpečím, nařizuje a organizuje evakuaci osob z ohroženého území obce, organizuje činnost obce $\mathrm{v}$ podmínkách nouzového přežití obyvatel obce, je oprávněn požádat právnické a fyzické osoby o poskytnutí dobrovolné pomoci, plní úkoly a opatření uvedená $\mathrm{v}$ krizovém plánu kraje, zajišt'uje organizaci dalších nezbytných opatření.

Všechny citované povinnosti ze zákona č. 239/2000 Sb., o integrovaném záchranném systému a o změně některých zákonů, ve znění pozdějších předpisů (dále jen ,zákon o IZS“) a zákona č. 240/2000 Sb., o krizovém řízení a o změně některých zákonů (krizový zákon), ve znění pozdějších předpisů (dále jen „krizový zákon“), jsou spojené s pravidelnou odbornou př́pravou. Tu by měl provádět dle výše citovaných zákonů obecní úřad obce $\mathrm{z}$ rozšířenou působností a Hasičský záchranný sbor kraje (dále jen HZS). Starosta obce o výše citovaných povinnostech musí mít povědomost, znát způsoby řešení různých situací a mít manažerské schopnosti.

K získávání a prohlubování těchto znalostí se v současné době také naskýtají různé formy vzdělávání. Např. vzdělávání starostů obcî v oblasti ochrany obyvatelstva v rámci celoživotního vzdělávání pořádané Jihočeskou univerzitou v Českých Budějovicích nebo semináře, konference a kongresy týkající se problematiky ochrany obyvatelstva, řešení a zvládání mimorádných událostí a krizových situací apod.

\section{Obecní úrad}

Dalším orgánem obce, který se podílí na zdárném a kvalitním řešení mimořádných událostí a krizových situací je obecní úrad. Jedná-li se o obce I. stupně či obce s pověřeným obecným úradem (II. stupně), zabezpečí tuto oblast starosta, popř. úředník, který vyřizuje úřední agen- 
du obecního úřadu. Tam, kde je zrrízena funkce tajemníka obecního úřadu, bude ji nejspíše vykonávat on.

$\mathrm{V}$ případě, že budeme mít na mysli obecní úrad obce $z$ rozšířrenou působností (III. stupně), předpokládáme, že je zde minimálně jeden úředník, který se danou problematikou zabývá. Má na starosti a zodpovídá za zabezpečení, vybavení vedení dokumentace a školení členů bezpečnostní rady určené obce a krizového štábu obce. Musí umět dobře vytipovat úředníky-členy krizového štábu obce, kteří budou flexibilní a budou se dobře orientovat $\mathrm{v}$ dané problematice.

Úředník - krizový manager - musí splňovat podmínky zákona č. 312/2002 Sb., o úřrednících územních samosprávných celků a o změně některých zákonů, ve znění pozdějších předpisů. Za obecní úřad zajišt'uje a organizuje prripravenost obce na mimořádné události a podílí se na provádění záchranných a likvidačních prací s integrovaným záchranným systémem a na ochraně obyvatelstva, nap̌r.:

- zajišt'uje varování, evakuaci a ukrytí osob před hrozícím nebezpečím, pokud zvláštní právní předpis nestanoví jinak;

- hospodaří s materiálem civilní ochrany (v současné době není aktuálnî);

- poskytuje hasičskému záchrannému sboru kraje podklady a informace potřebné ke zpracování havarijního plánu kraje nebo vnějšího havarijního plánu;

- podílí se na zajišstění nouzového přežití obyvatel obce;

- vede evidenci a provádí kontrolu staveb civilní ochrany nebo staveb dotčených požadavky civilní ochrany v obci;

- seznamuje právnické a fyzické osoby v obci s charakterem možného ohrožení, s připravenými záchrannými a likvidačními pracemi a ochranou obyvatelstva. Za tímto účelem organizuje jejich školení, informuje na webových stránkách obce, vydává informace ve zpravodaji nebo $\mathrm{v}$ príručce pro obyvatele, může $\mathrm{k}$ informování osob využít masmédia jako denní tisk, regionální rozhlas či kabelovou televizi v prípadě, že je ve městě provozována.

Všechny vyjmenované povinnosti vyplývají ze zákona o IZS.

Před vyhlášením krizového stavu a i v době po jeho vyhlášení je povinen organizovat prípra- vu obce na krizové situace, rozpracovávat úkoly krizového plánu kraje, poskytuje hasičskému záchrannému sboru kraje podklady a informace potřebné ke zpracování krizového plánu kraje, shromažd'uje údaje o počtu a totožnosti osob, které $\mathrm{v}$ době krizového stavu přechodně změnily pobyt a nachází se na správním území obce a předává tyto údaje krajskému úřadu a do ústřední evidence o přechodných změnách pobytu osob, podílí se na zajištění veřejného porádku, plní další úkoly stanovené krajským úřadem při př́pravě na krizové situace a jejich řešení, seznamuje právnické a fyzické osoby s charakterem možného ohrožení, s připravenými krizovými opatřeními a se zpo̊sobem jejich provedení.

Vzhledem k rozličnému charakteru různých mimořádných událostí musí být znalosti tohoto či těchto pracovníků multidisciplinární. S tím vším se pojí velmi dobrá znalost právních předpisů, operačních systémů, podpůrných softwarů, znalost místopisu, mít obecný přehled o důležitých právnických a podnikajících fyzických osobách na území obce či celého správního obvodu apod. V neposlední řadě musí být psychicky odolným a dobrým organizátorem.

Jako u starosty, tak i v tomto prrípadě mohou být zvoleny různé formy vzdělávání. V první řadě je to vzdělávání $\mathrm{v}$ Institutu pro místní správu Praha a Institutu ochrany obyvatelstva v Lázních Bohdaneč. Dále pak na univerzitách a u právnických osob, které nabízejí různé studijní programy, kurzy či celoživotní vzdělávání, semináře, konference a kongresy týkající se problematiky ochrany obyvatelstva, řešení a zvládání mimořádných událostí a krizových situací apod. Samozřejmě pouhým studiem se z nikoho schopný odborník nestane. Čím déle je tento pracovník ve funkci, tím více různých událostí řeší a získává cenné zkušenosti. Ty si pak mohou pracovníci krizového řízení předávat na seminárích, poradách apod.

Městský úřad Písek každoročně provádí cvičení nebo školení členů krizového štábu. Oddělení krizového řízení zvolilo jakousi periodu, kdy 2 roky po sobě jsou 2 cvičení a 3. rok po nich následující je provedena odborná prríprava krizového štábu. Tento systém se osvědčil, protože i na městském úradu dochází $\mathrm{k}$ výměně či $\mathrm{k}$ obměně zaměstnanců a to má návaznost na složení krizového štábu. 


\section{JEDNOTKA SBORU DOBOROVOLNÝCH HASIČŮ OBCE}

Vznik a činnost jednotky sboru dobrovolných hasičů obce (dále jen ,JSDHO“) a jejich členů je spojena se zákonem č. 133/1985 Sb., o požární ochraně, ve znění pozdějších předpisů (dále jen „zákon o $\left.P \mathrm{O}^{“}\right)$, dalších právních předpisů, směrnic a řádů, které na tento zákon navazují.

Aby činnost JSDHO byla co nejkvalitnější, nejúčinnější a nejefektivnější, musí být prováděna rovněž pravidelná, tedy cyklická odborná př́prava. Ta je u naší městské jednotky prováděna několika zpo̊soby. Odborná príprava vyplývá také $\mathrm{z}$ toho jaké materiální a technické vybavení JSDHO vlastní a obhospodařuje. $\mathrm{V}$ dnešní době se od obsluhy mnoha různých pomůcek, strojů a zařízení vyžaduje vlastnictví speciálních oprávnění a certifikátů pro práci s nimi.

Velitel jednotky, velitelé družstev, strojníci a nositelé dýchací techniky jsou pravidelně školeni pŕíslušníky HZS. Jednou za pět let skládají ve své odbornosti zkoušku (to se netýká nositelů dýchací techniky).

Město Písek má ve své JSDHO také další odbornosti jako řidiče hasičských vozidel, vůdce malých plavidel, specialisty, kteř́ mají oprávnění pracovat spřenosnou řetězovou pilou a křovinořezem a také zdravotníky. Aby mohli vykonávat své funkce, musí jim město zajistit pravidelnou odbornou př́pravu.

- Ǩidiči hasičských vozidel musí splňovat podmínky \ 72 zákona PO, \37 vyhlášky MV č. 247/2001 Sb., o organizaci a činnosti jednotek požární ochrany, ve znění pozdějších předpisů, vyhlášky MDaS č. 167/2002 Sb., kterou se provádí zákon č. 247/2000 Sb., o získávání a zdokonalování odborné způsobilosti $\mathrm{k}$ řízení motorových vozidel a o změnách některých zákonů, ve znění zákona č. 478/2001 Sb., ve znění pozdějších předpisů a Čl. 11 odst. 1 Pravidel pro používání požární techniky, schválených usnesením č. 326/99 ze dne 2. záŕí 1999 radou města Písku.

- Specialista pracující s přenosnou řetězovou pilou musí splňovat podmínky \ 72 zákona ČNR č. 133/1985 Sb. o požární ochraně (dále PO), v platném znění, \ 37 vyhlášky MV č. 247/2001 Sb. o organizaci a činnosti jednotek požární ochrany, ve znění pozdějších předpisů a nařízení vlády č. 28/2002 Sb., kterým se stanoví způsob organizace práce a pracovních postupů, které je zaměstnavatel povinen zajistit při práci $\mathrm{v}$ lese a na pracovištích obdobného charakteru a Čl. 5 odst. 1 Pravidel pro používání požární techniky, schválených usnesením č. 326/99 ze dne 2. záŕí 1999 radou města Písku.

- Vůdce malého plavidla musí splnit podmínky 』 16 zákona č. 114/1995 Sb., o vnitrozemské plavbě, ve znění pozdějších předpisů a vyhlášky MD č. 224/1995 Sb., o způsobilosti osob k vedení a obsluze plavidel.

Jako poslední provádí odbornou přípravu svých členů JSDH velitel jednotky požární ochrany. Jednak využívá všechny dostupné právní předpisy, směrnice a řády a také pokyn MV - GŔ HZS ČR s názvem „Hlavní zaměření odborné přípravy". Ten obsahuje témata, která v tom daném roce jsou aktuální a JSDHO v celé naší republice je mají procvičit či se s nimi seznámit. Velitel jednotky dále provádí celoročně (každých 14 dní v rozsahu 4 vyučovacích hodin) dle $\int 72$ zákona o PO a \ 36 až 40 odst. vyhlášky o JPO, ve znění pozdějších předpisů, odborné př́pravy JSDH. Tyto př́pravy zahrnují teoretickou pŕípravu (cvičební řád JPO, nebezpečí na místě zásahu, druhy nebezpečí a principy ochrany zdraví a životů hasičů, záchranu osob, zvírat a majetku, spojovací službu, plošné rozmístění jednotek požární ochrany v rámci okresu Písek a působnost JSDHO v něm, Požární rád města Písek, zákon o PO a jeho vyhlášky, prevenci a předcházení požárům nebo jiným mimořádným událostem, seznámení s riziky ohrožení okresu Písek se zaměřením na území města Písek), praktický výcvik (práci s motorovou pilou a křovinořezem, dálkovou dopravu vody a práce na vodě, výcvik při práci ve výškách a nad volnou hloubkou, způsoby jištění a sebezáchrany osob).

\section{ZÁVĚR}

Co říci závěrem. Současná doba je opravdu hektická. Občané žádají po záchranářích i úřednících co nejrychlejší a vysoce kvalifikovanou ochranu jejich života, zdraví a majetku. To bohužel bez kvalitních, dobře vycvičených a připravených krizových managerů a záchranářu nejde.

Můžeme mít v krizovém štábu ty nejschop- 
nější osoby, pokud však $\mathrm{v}$ něm budou pouze formálně najmenováni, v nějaké dokumentaci uvedeni a nebudou nic vědět o způsobu práce krizového štábu, řešení mimořádných událostí či krizových situací, bude jejich účast úplně zbytečná možná i na obtíž.

Rovněž můžeme mít sebelépe vybavenou jednotku požární ochrany těmi nejmodernějšími technickými prostředky, pokud však její členové nebudou pravidelně cvičeni a školeni, nebudou mít potřebná oprávnění či certifikáty, bude jejich činnost při zásahu chaotická a tristní. Získánî všech oprávnění bezesporu vyžaduje i finanční prostředky. Vzhledem k zachráněným životům, zdraví, majetku a škodách na životním prostředí se tato investice bohatě vyplatí.

\section{PŘÍLOHA}

\section{Materiální a technické vybavení JSDH}

města Písek:

- Cisterna automobilová stříkačka LIAZ 101.860 CAS 25 (stáří 20 let) - repasovaná $\mathrm{v}$ roce 2005.

- Dopravní automobil AVIA $31 \mathrm{~K} / 5$ (stáŕí 20 let) - přestavěná v roce 2006.

- Přívěsná přenosná stř́ikačka PPS 12.

- Přenosná stř́kačka PS 16.

- Přenosná strŕkačka PS 12.

- Plovoucí motorová přenosná strríkačka

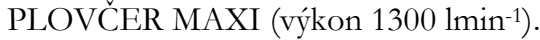

- Plovoucí motorová přenosná stř́kačka

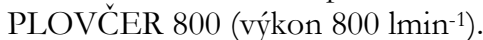

- Kalové čerpadlo 80-KDDF-LR-E 400V.

- Elektrocentrála HONDA ECMT 6500 K1 F.

- Elektrogenerátor ELEMAX 2,6 kVA.

- Hliníková lod’ MARINE 16 Y s kapacitou 7 osob.

- $\quad$ Lodní motor MERCURY 50 ELPTO.

- Jednoosý bržděný přívěs pro přepravu lodí PL7BD.

- Jednoosý nebržděný nákladní přívěs NP 21.

- Nafukovací člun DINGHY 500 s kapacitou 9 osob.

- Závěsný motor SUZUKI DT 15 C.

- Rybářská pramice s úpravami pro hasiče.
- Izolační dýchací přístroj PLUTO - 4 soupravy.

- Náhradní kompozitní láhve pro izolační dýchací prrístroje PLUTO - 4 kusy.

- Retězová motorová pila PARTNER 510 CCS.

- Řetězová motorová pila HUSQVARNA 372 XP.

- Řetězová motorová pila HUSQVARNA 372 XPG (vyhřívaná rukojet').

- Rozbrušovací pila DOLMAR PC 8116.

- Křovinořez PARTNER B 405.

- Vysokotlaký čistič KRÄNZLE 175 T.

- Vozidlová radiostanice MOTOROLA GM 340 Popular.

- Přenosná radiostanice MOTOROLA GP $300-3$ soupravy.

- Pagery s vibrací KEY NOTE MOTOROLA - 20 kusů.

- Nafukovací stan SU 680 s osvětlením vnitřní plocha $45 \mathrm{~m}^{2}$

- Svářecí zdroj POWER max2.

- Úhlová bruska (rozbruska s diamantovým kotoučem) METABO W 2031 X.

\section{LITERATURA}

Zákon č. 133/1985 Sb., o požární ochraně, ve znění pozdějších předpisů.

Zákon č. 239/2000 Sb., o integrovaném záchranném systému a o změně některých zákonů, ve znění pozdějších predpisů.

Zákon č. 240/2000 Sb., o krizovém řízení a o změně některých zákonů (krizový zákon), ve znění pozdějších předpisů.

Vyhláška Ministerstva vnitra č. 247/2001 Sb., o organizaci a činnosti jednotek požární ochrany.

Vyhláška MDaS č. 167/2002 Sb., kterou se provádí zákon č. 247/2000 Sb., o získávání a zdokonalování odborné způsobilosti $\mathrm{k}$ řízení motorových vozidel a o změnách některých zákonů, ve znění zákona č. 478/2001 Sb., ve znění pozdějších předpisů.

Nařízení vlády č. 172/2001 Sb., k provedení zákona o požární ochraně.

Nařízení vlády č. 28/2002 Sb., kterým se stanoví způsob organizace práce a pracovních postupů, které je zaměstnavatel povinen zajistit při práci $\mathrm{v}$ lese a na pracovištích obdobného charakteru. 